\title{
Dampak Sosio Spasial Pembangunan Kompleks Perumahan Terhadap Penduduk Desa Taeng Kabupaten Gowa (Tinjauan Sosiologi Spasial)
}

\author{
Jamaluddin Arifin \\ Dosen Pendidikan Sosiologi FKIP Universitas Muhammadiyah Makassar \\ Email: jamaluddinarifin@unismuh.ac.id
}

\begin{abstract}
This study aims to obtain in-depth information about the socio-spatial impact of development on residential of Taeng Village, Pallangga District, Gowa Regency. Meanwhile, the specific target to be achieved in this research is theoretically expected to contribute to the development of spatial sociology, while practically it can be a reference for the local government to formulate policies to overcome the negative impacts resulting from the construction of residential. The type of research used is qualitative with a case study approach in the perspective of spatial sociology. In collecting data, the researcher himself acts as the main instrument using supporting tools, data collection techniques through observation, in-depth interviews and documentation. The analysis technique is inductive, namely analyzing the socio-spatial impact of residential developments The results showed that there are two socio-spatial impacts of the construction on the residential of Taeng Village, Pallangga District, Gowa Regency, namely the positive impacts including: a. The increase of economic activity through land use; $b$. The creation of new employment opportunities for the indigenous or local population, while the negative impacts include a. The administration of population data is not in order, b. Partial emergence of slums on the edge of the village. c. Limited social interaction between villagers.
\end{abstract}

Keywords : Socio, Spatial, Residential

\begin{abstract}
Abstrak. Penelitian ini bertujuan untuk memperoleh informasi yang mendalam tentang dampak sosio spasial pembangunan kompleks perumahan terhadap penduduk Desa Taeng Kecamatan Pallangga Kabupaten Gowa. Sementara itu, target khusus yang akan dicapai dalam penelitian ini yaitu secara teoritis diharapkan dapat berkonstribusi dalam perkembangan ilmu sosiologi spasial sedangkan secara praksis yakni dapat menjadi rujukan bagi pemerintah setempat untuk merumuskan kebijakan dalam menanggulangi dampak negatif akibat dari pembangunan kompleks perumahan. Jenis penelitian yang digunakan adalah kualitatif dengan pendekatan studi kasus dalam perspektif sosiologi spasial. Dalam mengumpulkan data, peneliti sendiri bertindak sebagai instrumen utama dengan menggunakan alat pendukung, teknik pengumpulan data melalui observasi, wawancara mendalam dan dokumentasi. Teknik analisis dengan cara induktif, yakni menganalisis dampak sosio spasial pembangunan kompleks perumahan. Hasil penelitian menunjukkan bahwa dampak sosio spasial pembanguan kompleks perumahan terhadap penduduk Desa Taeng Kecamatan Pallangga Kabupaten Gowa ada dua yaitu dampak positif meliputi : a. Peningkatan aktivitas ekonomi melalui pemanfaatan lahan $b$. Terciptanya lapangan kerja baru penduduk asli atau lokal sedangkan dampak negatifnya meliputi a. Pengadministrasian data kependudukan tidak tertib, b. Munculnya secara parsial pemukiman kumuh (slums) dipinggiran desa. c. Interaksi sosial antar penduduk desa terbatas.
\end{abstract}

Kata Kunci : Sosio, Spasial, Kompleks, Perumahan 


\section{PENDAHULUAN}

Kajian tentang pembangunan kompleks perumahan dalam perspektif sosiologi spasial telah banyak dilakukan oleh para ahli sosiolog dan ilmuan di bidang pengkajian perkotaan. melalui pemikiran Howard: 1898 dalam bukunya, "Garden Cities of Tomorrow" yang menjadi pola dasar spasial pemukiman kota taman diberbagai kota didunia. Sebuah konsep kota taman terbuka untuk mengatasi masalah-masalah yang ditimbulkan dari revolusi industri. Banyaknya masalah yang timbul seperti asap tebal dari pabrik-pabrik serta kepadatan pemukiman akhinya memperburuk kesehatan masyarakat dimasa itu. Sejalan dengan berkembangnya waktu dan dengan prilaku sekelompok masyarakat yang semakin ekslusif, sehingga berubah bentuknya menjadi pola pemukiman tertutup sebagaimana prinsip-prinsip kehidupan masyarakat yang mengejar kehidupan penuh kebahagiaan yang bertumpu dari anak tangga hirarki kebutuhan dijabarkan kedalam pola spasial pemukiman (Maslow, 1943).

Persoalan utama yaitu alasan keamanan sehingga konstruksi fisik pemukiman tersebut dikelilingi dinding pagar, pintu keluar masuk yang selalu terjaga dan keamanan kawasan yang dilakukan oleh pihak pengelola menjadi salah satu unsur dasar perancangan pemukiman yang disebut dengan Komunitas Pintu Gerbang (KPG) (Low, 2004; Blakely dan Snyder, 1997). Komunitas Pintu Gerbang (KPG) kemudian diadopsi oleh kota-kota besar di Indonesia dan mulai berkembang sekitar tahun 1990an. Perkembangan Komunitas Pintu Gerbang KPG) merupakan fitur baru bagi pembangunan kota masa kini. Pola spasial dan konstruksi fisik berkembang secara kompetitif di wilayah pusat maupun wilayah pinggiran kota. Pada wilayah pusat kota, tipologi Komunitas Pintu Gerbang (KPG) diwujudkan dalam bentuk apartemen dan town house serta hunian multiguna (mixuse) berupa superblock yang dipagari oleh dinding tinggi, wilayah pinggiran kota, KPG (Komunias Pintu Gerbang) diwujudkan dalam betuk pemukiman dengan luas berskala kecil, sedang maupun besar.

Keberadaan kompleks perumahan yang merupakan entitas tertutup dengan menggunakan pagar dan pintu masuk-keluar mempertegas kesan ekslusivitas dari sebuah ruang. Menurut Hendrastomo (2012), munculnya kelompok sosial berdasarkan pemilihan ruang yang sama disatu sisi disadari sebagai gaya hidup baru masyarakat kontemporer, tetapi disisi lain menimbulkan potensi konflik yang berakar dari kesenjangan yang muncul dari komunitas berpagar dengan komunitas tradisional (kampung). Potensi konflik muncul akibat kesenjangan ekonomi, ketercerabutan interaksi sosial dengan masyarakat sekitar yang menimbulkan pertentangan, konflik hingga vandalisme. Sementara itu dikemukakan oleh Diningrat (2015), bahwa kesengajaan mendesain ruang-ruang yang tersegregasi dalam rangka mewadahi keinginan penduduk untuk mengeksklusifkan diri, di sisi lain dapat memberi dampak negatif berupa semakin renggangnya hubungan kekerabatan antar penduduk. Hal ini dikarenakan sekat-sekat fisik seolah memberi kesan tentang batas ruang mana yang perlu dikenali dan juga ruang yang tidak perlu dikenali.

\section{METODE PENELITIAN}

Jenis penelitian yang digunakan yakni kualitatif dengan pendekatan studi kasus yang mengkaji dan menganalisis dampak sosio spasial pembangunan kompleks perumahan terhadap penduduk Desa Teng Kecamatan Pallangga Kabupaten Gowa. Pertimbangan ini sesuai dengan harapan dalam mengfungsikan metode kualitatif agar dapat meyelami permasalahan secara aktif yaitu upaya melalui penalaran pikiran dan perasaan sekaligus berusaha memahaminya secara taksonomikal dimana pada gilirannya mampu menghasilkan proposisi-proposisi tentang formulasi dalam upaya menganalisa kemengapaan pada fokus penelitian. Sebagimana Creswel (2003) menyatakan bahwa, penelitian kualitatif adalah pendekatan untuk membangun pernyataan pengetahuan berdasarkan perspektif konstruktif (contoh: makna-makna yang bersumber dari pengalaman individu, nilai-nilai sosial dan sejarah, dengan tujuan untuk membangun teori atau pola pengetahuan tertentu).

Penelitian ini dilaksanakan di Desa Taeng Kecamatan Pallangga Kabupaten Gowa dengan karakteristik geografisnya merupakan wilayah dataran rendah, \pm 100 meter di atas permukaan laut, persawahan di desa tersebut termasuk sawah tadah hujan. Letak tempat penelitian berada di 
sebelah barat ibukota kabupaten dengan tipologi termasuk desa persawahan atau desa dataran rendah.

Penelitian ini berfokus pada dampak sosio spasial yang ditimbulkan dari pembangunan kompleks perumahan di Desa Taeng Kecamatan Pallangga Kabupaten Gowa. Untuk mengetahui lebih mendalam hal tersebut, peneliti mengambil data dari informan dengan teknik berantai (snow ball), dari ciri-cirinya seperti: (1) Informan tidak ditarik atau ditentukan terlebih dahulu; (2) Informan dipilih atas dasar fokus penelitian; (3) Informan ditentukan oleh pertimbangan-pertimbangan informasi yang diperlukan, informasi selanjutnya diambil dari petunjuk informan sebelumnya, data atau informasi yang dikumpulkan berakhir pada titik kejenuhan, yaitu jika informasi yang didapatkan telah berulan-ulang dari informan yang berbeda (Moleong, 2012).

Adapun informan yang dimaksud terdiri dari: (1) Pemerintah Desa Taeng dalam hal ini kepala desa dan beberapa staf desa sebagai informan yang memberikan keterangan terkait tujuan penelitian pertama dan ketiga (2) Kepala Dusun dan beberapa tokoh masyarakat desa sebagai informan yang memberikan keterangan terkait ujuan penelitian pertama dan ketiga (3) Pengembang (developer) dalam hal ini dikategorikan menjadi dua baik pengembang (developer) perumahan bersubsidi dan komersil sebagai informan yang memberikan keterangan terkait tujuan peneltian pertama dan kedua (4) Penduduk Desa Taeng baik yang tinggal didalam kompleks perumahan dan penduduk asli atau lokal yang notabene tinggal diluar kompleks perumahan atau di perkampungan sebagai informan yang memberikan keerangan pada tujuan penelitian pertama, kedua dan ketiga (5) penduduk desa lainnya yang dianggap bisa memberikan tambahan keterangan pada tujuan penelitan pertama, kedua dan ketiga.

Pengumpulan data atau informasi dilakukan langsung oleh peneliti dengan menggunakan tiga teknik yaitu: observasi (pengamatan terlibat), wawancara mendalam (depth interview) dan dokumentasi. Teknik analisis data yang dilakukan dalam penelitian ini adalah secara induktif melalui pengorganisasian data, menjabarkannya ke dalam unit-unit, melakukan sintesa, menyususn ke dalam pola, memilih mana data penting dan membuat kesimpulan. Dalam penelitian ini, teknik pengabsahan data yang penulis gunakan adalah perpanjangan keikutsertaan, ketekunan pengamatan, trianggulasi, pengecekan sejawat, analisis kasus negatif, kecukupan referensi, pengecekan anggota, uraian rinci dan audit trail (Moleong, 2002 ; Sugiyono, 2006).

\section{HASIL PENELITIAN DAN PEMBAHASAN}

\section{A. Keadaan Geografis Lokasi Penelitian}

Desa Taeng merupakan bagian dari Kecamatan Pallangga Kabupaten Gowa. Desa Taeng yang luas keseluruhan wilayahnya $\pm 336,3 \mathrm{~km}^{2}$ (Sumber data: Kantor BPS Kabupaten Gowa Tahun 2011). Desa Teng sebagian besar merupakan daratan dan juga memiliki sungai dengan panjang \pm 1 $\mathrm{km}$ dengan luas aliran sungai 0,25 km. Sedangkan batas-batas wilayah di Desa Taeng adalah :

1. Sebelah Utara berbatasan dengan Sungai Je'neberang

2. Sebelah Timur berbatasan dengan desa Bontoala

3. Sebelah Selatan berbatasan dengan Desa Bontoala/Kanjilo

4. Sebelah Barat berbatasan dengan Tamanya'lang

1. Kondisi Demografis

Desa Taeng merupakan salah satu desa di kecamatan Pallangga kabupaten Gowa dengan luas wilayah $336,3 \mathrm{~km}^{2}$ terdiri dari dua lingkungan yaitu: lingkungan I Taeng dan lingkungan II Gantarang. Menurut data kependudukan tahun 2014 tercatat \pm 9.044 jiwa dari 3.207 kepala keluarga dan angka itu terus meningkat dari tahun ketahun sampai saat ini. Desa Taeng memiliki banyak potensi unggulan baik itu potensi yang bersumber dari manusia maupun potensi yang bersumber dari alam.

Potensi unggulan desa ini antara lain potensi budaya. Desa Taeng yang masih menjunjung tinggi nilai-nilai budaya tradsional. Kegiatan budaya ini baik kepada pesta perkawinan, kematian ddan juga kelahiran. Semua ini tidak terlepas dengan semangat untuk tetap mempertahankan budaya tradisional yang masih terjaga. Desa Taeng juga terkenal dengan badik De'de Taeng yang 
merupakan senjata tradisional yang digunakan pada saat melawan penjajah. Selain itu ada lagiproduk unggulan lainnya adalah sarung sutera. Pembuatan sarung sutera ini masih menggunakan lat tenun yang masih ttradisional. Satu sarung memerlukan waktu sekitar 20 hari. Sarung sutera Cura Labba sering dipesan oleh pejabat pemerintah Kabupaten Gowa untuk dijadikan cindera mata jika ada pejabat yang berkunjung ke kabupaten Gowa.

2. Kondisi Sarana dan Prasarana

Pembangunan dalam penyediaan sarana dan pra sarana dalam memberikan pelayanan sosial dapat dilihat dari tersedianya sarana dan prasarana dalam menyediakan segala kebutuhan masyarakat dalam lingkungan. Seperti sarana dan prasarana pendidikan, kesehatan, dan sarana keagamaan.

\section{a. Sarana Pendidikan}

Pendidikan merupakan suatu hal yang memiliki peranan penting dalam kehidupan. Pendidikan sangat berperan dalam pembentukan pola pikir dalam pengembangan kualitas hidup masyarakat, dan ketersediaan sarana mauipun prasarana. Pendidikan merupakan suatu kebutuhan masyarakat yang sangat mendukung dalam pengembangan masyarakat. Lebih jelasnya dapat dilihat pada tabel sebagai berikut :

Tabel 1.1: Distribusi Jumlah Sarana Pendidikan

\begin{tabular}{|c|l|c|}
\hline No & \multicolumn{1}{|c|}{ Sarana Pendidikan } & Jumlah \\
\hline 1 & Taman Kanak-Kanak & 4 \\
\hline 2 & TPA & 3 \\
\hline 3 & Sekolah Dasar Sederajat & 1 \\
\hline 4 & Sekolah Menengah Pertama (SMP) sederajat & 1 \\
\hline 5 & Sekoah Menengah Atas (SMA ) sederajat & \\
\hline
\end{tabular}

Sumber: Kantor Desa Taeng 2019

Berdasarkan data tersebut menunjukkan bahwa Desa Taeng memiliki jumlah sarana pendidikan seperti yang ditunjukkan dari tabel diatas yang terdiri dari 25 gedung yaitu sekolah dasar/sederajat berjumlah 3 unit, Taman Kanak-Kanak sebanyak 4 unit, taman TPA 16 unit.

b. Sarana Keagamaan

Dalam hal keagamaan penduduk Desa Taeng rata-rata menganut agama Islam. Sarana keagamaan di Desa Taeng hanya terdiri dari sarana peribadatan berupa Masjid yang berjumlah 7 buah dan tidak terdapat rumah peribadatan yang lain.

c. Sarana kesehatan

Terpenuhnya kebutuhan masyarakat dalam hal kebutuhan akan kesehatan dapat dilihat dari tersedianya sarana dan prasarana kesehatan yang ada di dalam lingkungan masyarakat. Seperti di desa Taeng terdapat sarana dan prasarana kesehatan seperti yang ditunjukkan pada tabel berikut ini :

Tabel 1.2: Distribusi Jumlah Sarana dan Prasarana Kesehatan Desa Taeng

\begin{tabular}{|c|l|c|}
\hline No & \multicolumn{1}{|c|}{ Sarana/prasarana Kesehatan } & Jumlah \\
\hline 1 & Puseksmas/Pustu & 2 \\
\hline 2 & Posyandu & 3 \\
\hline 3 & Klinik Bersalin & 1 \\
\hline
\end{tabular}




\begin{tabular}{|c|l|c|}
\hline 4 & Dokter Praktek & 1 \\
\hline
\end{tabular}

Sumber : Kantor Desa Taeng 2019

\section{B. Dampak Sosio Spasial Pembangunan Kompleks Perumahan Terhadap Penduduk Desa Taeng Kecamatan Pallangga Kabupaen Gowa}

Segregasi sosio spasial yang berlangsung di Desa Taeng berdampak positif dan negatif.

\section{a. Dampak Positif}

1) Peningkatan aktivitas ekonomi melalui pemanfaatan lahan.

Menjamurnya pembangunan kompleks perumahan yang tersebar dibeberapa titik membawa dampak baik pada kondisi fisik desa mapun kondisi sosial masyarakatnya. Dampak tersebut terlihat dari, pola pikir dan pola prilaku penduduk asli atau lokal. Adanya perubahan orientasi dalam memaknai suatu ruang atau lahan memiliki nilai ekonimis sehingga dimanfaatkan untuk kegiatan perdagangan.

2) Terciptanya lapangan kerja baru bagi penduduk asli atau lokal.

Proses pembangunan kompleks perumahan melahirkan hubungan saling membutuhkan dan ketergantungan antara pengembang (developer) dengan penduduk asli atau lokal. Keberadaan kompleks perumahan tidak hadir begitu saja namun melalui serangkaian proses yang panjang. Pembangunan pada aspek fisik kompleks perumahan yang memerlukan sumber daya yang banyak sehingga pengembang (developer) memanfaatkan sumber daya penduduk asli atau lokal sebagai pekerja dalam proses pembangunan kompleks perumahan. Penduduk asli atau lokal didesa Taeng yang sebagian tidak memliki pekerjaan tetap dan ada pula membutuhkan pendapatan tambahan sehingga dengan begitu terbentuk hubungan kerjasama. Pengembang (developer) yang datang menguasai lahan namun pada sisi tertentu berdampak positif karena pengembang (developer) memanfaatkan sumber daya penduduk asli lokal dengan mempekerjakannya sebagai buruh atau pekerja bangunan yang bagi penduduk asli atau lokal hal tersebut adalah lapangan kerja baru.

Selain itu pemanfaatan jasa penduduk asli atau lokal oleh penduduk kompleks perumahan sebagai petugas keamanan atau sekuriti kompleks perumahan sebagai asisten rumah tangga. Tercatat dua puluh empat kompleks perumahan semuanya menggunakan masing-masing dua petugas keamanan atau sekuriti dengan tugas sistem sift atau bergantian. Kedua petugas kemanan atau sekuriti tersebut secara bergantian melakukan tugas penjagaan, ada yang bertungas pagi sampai petang dan ada yang bertugas petang sampai pagi. Dengan sistem penjagaan kompleks seperti itu maka kompleks terjaga selama dua puluh empat jam sehari semalam dari hal-hal yang meresahkan penduduknya.

Selanjutnya pemberdayaan penduduk asli atau lokal khususnya pada ibu rumah tangga yang tidak memliki pekerjaan tetap. Banyak kita bisa temukan di Desa Taeng Ibu rumah tangga diberdayakan oleh penduduk kompleks ada yang bekerja sebagai asisten rumah tangga yang tugasnya berbeda-beda tergantung dari penduduk yang mempekerjakannya. Ada yang tugasnya sebagai pengasuh anak, membersihkan rumah, atau juru masak. Namun setelah pekerjaannya sudah selesai maka asisten rumah tangga tersebut pulang kerumanhya lagi untuk melaksanakan tugas pokoknya baik itu sebagai istri maupun sebagi orang tua. Pemberdayaan ibu-ibu penduduk asli atau lokal mendapatkan upah sesuai dengan beban kerja yang diberikan.

\section{b. Dampak Negatif}

Selain dampak positif dari segregasi sosio spasial ditemukan pula beberapa dampak negatif yang sampai saat ini terus dilakukan upaya untuk mengatasinya, dampak negaitf tesebut antara lain :

1) Pengadministrasian data kependudukan tidak tertib

Adanya pembangunan kompleks perumahan menjadi pemicu terus bertambahnya penduduk Desa Taeng. Signifikannya pertambahan penduduk penduduk urban yang jumlahnya terus meningkat seiring dengan bertambanya pembangunan kompleks perumahan. Salah satu hal yang paling 
mendasari adalah longgarnya proses kepemilikan rumah secara administratif yang dipersyaratkan oleh pihak pengembang (developer), pihak per-Bank-an, dan pemerintah setempat berimplikasi pada konsumsi kebutuhan rumah tinggal penduduk urban sangat tinggi. Pertumbuhan penduduk yang terus meningkat dan tidak terkedali sehingga data administasi terkait dengan data kependudukan Desa Taeng tidak tertib. Beberapa hal yang menyebabkan itu terjadi. a) Syarat administasi kepemilikan rumah tidak terintegrasi secara online antara data yang dipersyaratkan oleh pihak pengembang (developer), pihak per-bank-an, dan pmerintah setempat dan b) Tidak ada kebijakan yang mengikat secara tegas tentang konsekwensi yang diterima oleh penduduk yang tidak memiliki identitas domisili, khusunya penduduk yang tinggal menetap.

2) Munculnya secara parsial pemukiman kumuh (slums) dipinggiran desa

Bermukimnya penduduk dibantaran sungai Je'neberang karena dampak pembangunan kompleks perumahan dan berlanjut menjadi relasi kekerabatan atau keluarga, solidaritas sosial dan pekerjaan merupakan legitimasi yang cukup kuat untuk terus mempertahankan keberadaannya sebagai penduduk yang menguasai suatu lahan yang tidak bertuan. Relasi yang telah disebutkan diatas merupakan kekuatan yang sekaligus tidak memberikan peluang kepada pemerintah setempat untuk merelokasi tempat tersebut karena telah menjadi sumber pendapatan pokoknya. Selain dari alasan diatas terkait dengan keberadaan mereka yang membetuk pemukiman kumuh adalah kemampuan ekonomi yang yang rendah sehingga sebagian penduduk yang bermukim menjual tanahnya dan rumahnya yang sebelumnya berada ditengah-tengah desa. Sebagian pula menjual tanahnya karena sudah terhimpit oleh pembangunan kompleks perumahan sehingga kondisi rumahnya tidak memiliki akses jalan. Keadaan tersebut sehingga mereka lebih memilih membangun rumah dibantaran sungan Je'neberang.

3) Interaksi sosial antar penduduk yang terbatas

Tersegregasinya Desa Taeng secara spasial dengan hadirnya kompleks perumahan yang berdampak pada hubungan sosial antar penduduk yang semakin jauh. Penduduk kompleks perumahan merasa tidak menjadi bagian dari kehidupan sosial dengan penduduk asli atau lokal. Hubungan sosial sesama penduduk asli atau lokal mengalami jarak karena dipengaruhi oleh pembangunan kompleks perumahan ditengah-tengah perkampungan penduduk asli atau lokal. Bahkan didalam kompleks perumahan juga nampak hubungan sosialnya tersegregasi antar kluster khususnya pada kompleks perumahan kategori komersil.

\section{KESIMPULAN}

Berdasarkan hasil dan pembahasan dari penelitian ini maka dapat disimpulkan bahwa dampak segregasi sosio spasial terhadap penduduk Desa Taeng Kecamatan Pallangga Kabupaten Gowa dibagi menjadi dua bentuk yaitu dampak positif dan dampak negatif, dampak positif dari segregasi sosio spasial terhadap penduduk Desa Taeng yaitu (a) Meningkatnya aktivitas ekonomi melalui pemanfaatan lahan (b) Terciptanya lapangan kerja baru bagi penduduk asli atau lokal, sedangkan dampak negaifnya yaitu (b) Pengadministrasian data kependudukan tidak tertib (b) Munculnya secara parsial pemukiman kumuh (slum) dipinggiran desa (c) Interaksi sosial antar penduduk desa terbatas.

\section{DAFTAR PUSTAKA}

Altinok, E., \& Cengiz, H. (2008, September). The effects of urban sprawl on spatial fragmentation and social segregation in Istanbul. In 44th ISOCARP Congress.

Aminah, Siti. 2015. Lab Sosio. Pusat Kajian Sosiologi FISIP-UI

Barnes, S. (2011). Gated Communities: a Discussion of the Reasons and the Consequences of Housing Choices Towards Increasingly Secure or Fortified Spaces in Western Cities. GEOView: Online Undergraduate Review of Geography and Environmental Studies. 
Blakely, E. J., \& Snyder, M. G. (1997). Fortress America: gated communities in the United States. Brookings Institution Press.

Bungin Burhan. 2011. Penelitian Kualitatif: Komunikasi, ekonomi, kebijakan public dan ilmu sosial lainnya.Jakarta. Kencana Prenada Group

Daldjoeni. 1982. Geografi Kesejarahan I (Peradaban Dunia). Bandung: Alumni.

Daskalova, Diliana \& Aleksandar D. Slaev. 2015. Diversity in the Suburbs: Socio-Spatial Segregation and Mix in Post-Socialist Sofia. Habitat International Journal 50, 42-50.

Diningrat, Rendy Adriyan, 2014, Jurnal Perencanaan Wilayah dan Kota.

Diningrat, R. A. (2015). Spatial Segregation of Large Scale Housing: The Case of Kota Harapan Indah New Town, Bekasi. Journal of Regional and City Planning, 26(2), 111-129.

Greenstein, R., F. Sabatini dan M. Smolka (2000) Urban Spatial Segregation: Forces

Harvey, D. (1985). The geopolitics of capitalism. In Social relations and spatial structures (pp. 128163). Palgrave, London.

Hendrastomo, G. (2012). Potensi Konflik Dibalik Munculnya Komunitas Berpagar (Gated Community). SOCIA: Jurnal IImu-IImu Sosial, 9(1).

Leaf, M (1994) The Suburbanization of Jakarta: a Concurrence of Economics and Ideology.

Lefebvre, Henri, 1991. The Production of Space. Translated by Donald Nicholson Smith, Oxford: Blackwell

Low, S. (2004). Behind the gates: Life, security, and the pursuit of happiness in fortress America. Routledge.

Moleong, Lexy. 1990. Metodologi Penelitian Kualitatif. Bandung: Remaja Rosda Karya

Oluwole, Olumide Akinwumi. 2013. Residential Mobility and Socio-Spatial Sorting in Kaduna Metropolis, Nigeria. Indonesian Journal of Geography, Vol.45, No. 2 (125-134).

Paturusi, S. A. (2016). Segregasi Ruang Sosial Antara Pendatang dengan Penduduk Asli pada Permukiman Perkotaan di Denpasar. Jurnal Kajian Bali (Journal of Bali Studies), 6(2), 57-78.

Salman, Darmawan. 2012.Sosiologi Desa (Revolusi Senyap dan Tarian Kompleksitas). Makassar: Ininnawa

Surya, B. (2016). Perubahan Fisik Spasial Kawasan Pinggiran Memarginalkan Komunitas Lokal (Kasus Kota Baru Metro Tanjung Bunga, Makassar). Tataloka, 13(4), 212-223.

Wulangsari, Amalia, 2014, Jurnal Pembanguan Wilayah dan Kota, Biro Penerbit Planologi Undip

Yunus, H. S. (2008). Dinamika wilayah peri-urban: determinan masa depan kota. Pustaka Pelajar. 